\title{
Article \\ Comparison of SARS-CoV-2 Detection by Rapid Antigen and by Three Commercial RT-qPCR Tests: A Study from Martin University Hospital in Slovakia
}

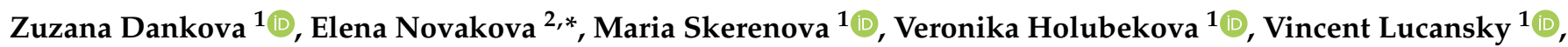 \\ Dana Dvorska ${ }^{1}$, Dusan Brany ${ }^{1}$, Zuzana Kolkova ${ }^{1}$, Jan Strnadel ${ }^{1}$, Sandra Mersakova ${ }^{1}$, Katarina Janikova ${ }^{1,3}$, \\ Marek Samec 1,4 ${ }^{\mathbb{D}}$, Michal Pokusa ${ }^{1}$, Martin Petras ${ }^{1}$, Miroslava Sarlinova ${ }^{1}$, Ivana Kasubova ${ }^{1}$, Dusan Loderer ${ }^{1}$, \\ Vladimira Sadlonova ${ }^{2}$, Jana Kompanikova ${ }^{2}$, Nina Kotlebova ${ }^{2}$ D, Adriana Kompanikova ${ }^{5}$, Martina Hrnciarova ${ }^{5}$, \\ Andrea Stanclova ${ }^{3}$, Martina Antosova ${ }^{6}$, Anton Dzian ${ }^{7}$, Vladimir Nosal ${ }^{8}$ (D), Ivan Kocan ${ }^{9}$, Dalibor Murgas ${ }^{10}$, \\ Dusan Krkoska ${ }^{11}$, Andrea Calkovska ${ }^{12}$ (D) and Erika Halasova ${ }^{1}$
}

check for

updates

Citation: Dankova, Z.; Novakova, E.; Skerenova, M.; Holubekova, V.; Lucansky, V.; Dvorska, D.; Brany, D.; Kolkova, Z.; Strnadel, J.; Mersakova, S.; et al. Comparison of SARS-CoV-2 Detection by Rapid Antigen and by Three Commercial RT-qPCR Tests: A Study from Martin University Hospital in Slovakia. Int. J. Environ. Res. Public Health 2021, 18, 7037. https://doi.org/10.3390/ ijerph18137037

Academic Editor: David Berrigan

Received: 20 April 2021

Accepted: 24 June 2021

Published: 1 July 2021

Publisher's Note: MDPI stays neutral with regard to jurisdictional claims in published maps and institutional affiliations.

Copyright: (c) 2021 by the authors. Licensee MDPI, Basel, Switzerland. This article is an open access article distributed under the terms and conditions of the Creative Commons Attribution (CC BY) license (https:// creativecommons.org/licenses/by/ $4.0 /)$
1 Biomedical Center Martin, Jessenius Faculty of Medicine in Martin, Comenius University in Bratislava, 03601 Martin, Slovakia; zuzana.dankova@uniba.sk (Z.D.); maria.skerenova@uniba.sk (M.S.); veronika.holubekova@uniba.sk (V.H.); vincent.lucansky@uniba.sk (V.L.); dana.dvorska@uniba.sk (D.D.); dusan.brany@uniba.sk (D.B.); zuzana.snahnicanova@uniba.sk (Z.K.); jan.strnadel@uniba.sk (J.S.); sandra.mersakova@uniba.sk (S.M.); chovancova64@uniba.sk (K.J.); marek.samec@uniba.sk (M.S.); michal.pokusa@uniba.sk (M.P.); martin.petras@uniba.sk (M.P.); miroslava.sarlinova@uniba.sk (M.S.); ivana.kasubova@uniba.sk (I.K.); dusan.loderer@uniba.sk (D.L.); erika.halasova@uniba.sk (E.H.)

2 Department of Microbiology and Immunology, Jessenius Faculty of Medicine in Martin, Comenius University in Bratislava, 03601 Martin, Slovakia; vladimira.sadlonova@uniba.sk (V.S.); jana.kompanikova@uniba.sk (J.K.); nina.kotlebova@uniba.sk (N.K.)

3 Department of Pathological Anatomy, Jessenius Faculty of Medicine in Martin, Comenius University in Bratislava, 03601 Martin, Slovakia; avoj@centrum.sk

4 Clinic of Obstetrics and Gynecology, Jessenius Faculty of Medicine in Martin, Comenius University in Bratislava, 03601 Martin, Slovakia

5 Hospital Hygiene Department, Martin University Hospital, 03601 Martin, Slovakia; kompanikova@unm.sk (A.K.); mhrnciarova@unm.sk (M.H.)

6 Modern Medical Leadership, s.r.o., 03601 Martin, Slovakia; matveja@gmail.com

7 Department of Thoracic Surgery, Martin University Hospital, Jessenius Faculty of Medicine in Martin, Comenius University in Bratislava, 03601 Martin, Slovakia; anton.dzian@uniba.sk

8 Clinic of Neurology, Martin University Hospital, Jessenius Faculty of Medicine in Martin, Comenius University in Bratislava, 03601 Martin, Slovakia; vladimir.nosal@uniba.sk

9 Clinic of Pneumology and Phthisiology, Martin University Hospital, Jessenius Faculty of Medicine in Martin, Comenius University in Bratislava, 03601 Martin, Slovakia; ivan.kocan@uniba.sk

10 Department of Pediatric Surgery, Martin University Hospital, Jessenius Faculty of Medicine in Martin, Comenius University in Bratislava, 03601 Martin, Slovakia; dalibor.murgas@uniba.sk

11 Department of Infectious Diseases and Travel Medicine, Martin University Hospital, Jessenius Faculty of Medicine in Martin, Comenius University in Bratislava, 03601 Martin, Slovakia; krkoska@unm.sk

12 Department of Physiology, Jessenius Faculty of Medicine in Martin, Comenius University in Bratislava, 03601 Martin, Slovakia; andrea.calkovska@uniba.sk

* Correspondence: elena.novakova@uniba.sk

Abstract: The global pandemic of coronavirus disease 2019 (COVID-19) caused by the severe acute respiratory syndrome coronavirus 2 (SARS-CoV-2) is having a tremendous impact on the global economy, health care systems and the lives of almost all people in the world. The Central European country of Slovakia reached one of the highest daily mortality rates per 100,000 inhabitants in the first 3 months of 2021, despite implementing strong prophylactic measures, lockdowns and repeated nationwide antigen testing. The present study reports a comparison of the performance of the Standard Q COVID-19 antigen test (SD Biosensor) with three commercial RT-qPCR kits (vDetect COVID-19-MultiplexDX, gb SARS-CoV-2 Multiplex-GENERI BIOTECH Ltd. and Genvinset COVID19 [E]-BDR Diagnostics) in the detection of infected individuals among employees of the Martin University Hospital in Slovakia. Health care providers, such as doctors and nurses, are classified as "critical infrastructure", and there is no doubt about the huge impact that incorrect results could have on patients. Out of 1231 samples, 14 were evaluated as positive for SARS-CoV-2 antigen presence, 
and all of them were confirmed by RT-qPCR kit 1 and kit 2 . As another 26 samples had a signal in the $E$ gene, these 40 samples were re-isolated and subsequently re-analysed using the three kits, which detected the virus in 22, 23 and 12 cases, respectively. The results point to a divergence not only between antigen and RT-qPCR tests, but also within the "gold standard" RT-qPCR testing. Performance analysis of the diagnostic antigen test showed the positive predictive value (PPV) to be $100 \%$ and negative predictive value (NPV) to be $98.10 \%$, indicating that $1.90 \%$ of individuals with a negative result were, in fact, positive. If these data are extrapolated to the national level, where the mean daily number of antigen tests was 250,000 in April 2021, it points to over 4700 people per day being misinterpreted and posing a risk of virus shedding. While mean $\mathrm{Ct}$ values of the samples that were both antigen and RT-qPCR positive were about 20 (kit 1: 20.47 and 20.16 for Sarbeco E and $R d R P$, kit 2: 19.37 and 19.99 for Sarbeco $E$ and $R d R P$ and kit 3: 17.47 for $O R F 1 b / R d R P$ ), mean Ct values of the samples that were antigen-negative but RT-qPCR-positive were about 30 (kit 1: 30.67 and 30.00 for Sarbeco E and RdRP, kit 2: 29.86 and 31.01 for Sarbeco $E$ and $R d R P$ and kit 3: 27.47 for $O R F 1 b / R d R P$ ). It confirms the advantage of antigen test in detecting the most infectious individuals with a higher viral load. However, the reporting of $\mathrm{Ct}$ values is still a matter of ongoing debates and should not be conducted without normalisation to standardised controls of known concentration.

Keywords: SARS-CoV-2; antigen; RT-qPCR; Ct; sensitivity; specificity; NPV—negative predictive value; PPV-positive predictive value

\section{Introduction}

Severe acute respiratory syndrome coronavirus 2 (SARS-CoV-2) belongs to the family Coronaviridae, genus Betacoronavirus and subgenus Sarbecoviruses [1]. The members of the Coronaviridae family are large RNA viruses, with enveloped viral particles ranging from $118 \mathrm{~nm}$ to $140 \mathrm{~nm}$ in diameter, bearing a single-stranded, positive RNA genome whose size ranges from 25 to $32 \mathrm{~kb}$, coding for 16 non-structural and 4 structural proteins [2,3]. They infect a wide variety of host organisms, including birds, rodents, carnivores, bats, marine mammals, primates and, importantly, humans [4,5]. Up to now, seven coronaviruses have been linked to human diseases. Four of them (HCoV-HKU1, HCoV-OC43, HCoV-229E, HCoV-NL63) usually cause only the common cold or rhinitis with mild symptoms. The other three have been responsible for outbreaks of severe acute respiratory syndrome with significant morbidity and mortality: namely, SARS-CoV in 2002, in Guangdong, China, with 744 deaths out of 8098 infections; MERS-CoV in Saudi Arabia in 2012, with 866 deaths out of 2621 infections; and SARS-CoV-2, which emerged in Wuhan, China, at the end of 2019 and has since given rise to ongoing world-wide pandemic [3,4]. The first recorded cases were patients suffering from unusual viral pneumonia that, after initial ambiguities, was connected with a coronavirus of (at that time) unknown origin [6]. Later on, phylogenetic analysis suggested that bats might be the original host $[7,8]$.

Only a few weeks later, on 30 January 2020, the WHO declared a global health emergency in response to COVID-19, the disease caused by SARS-CoV-2. According to WHO data, more than 128 million cases of COVID-19 and more than 2.8 million COVID19-associated deaths were reported by 1 April 2021, when this article was completed [9]. Slovakia recorded its first case on 6 March 2020. From then to 1 April 2021, there were 362,489 confirmed cases of COVID-19 with 9790 deaths in Slovakia [10]. Despite early successes in containing the pandemic, the Slovak Republic became one of the countries with the highest daily COVID-19 death toll per 100,000 inhabitants during the first 3 months of 2021. The disease overran the health care system and brought it close to collapse. It also disrupted the economic and political situation. The first steps of the Slovak authorities to slow down the spread of the virus were the declaration of a state of emergency on 12 March 2020 and the introduction of strong anti-epidemic measures and border restrictions. Inspired by the example of South Korea [11], it started testing for the presence of the SARS-CoV-2, utilising the RT-qPCR method and introduced a mandatory quarantine for 
people coming from abroad. In spite of the measures taken by the Slovak Government and an increase in the volume of testing, the incidence of SARS-Cov-2-positive individuals began to grow rapidly in the autumn of 2020. Based on this situation, and in order to detect hotspots of infection, the Slovak Republic carried out a nationwide screening campaign using an antigen test (Standard Q COVID-19 Ag test, SD Biosensor) on 31 October and 1 November and subsequently on 8 November and 9 November 2020. The results and mathematical models of its effectivity were published by Pavelka et al. (2020) and Frnda and Durica $(2020)[12,13]$. Despite the achievement of a short-term reduction in cases, the epidemic situation rapidly deteriorated and became critical. The number of active cases and daily deaths continued to escalate [14] even after the introduction of more stringent measures. The tide did not turn until March 2021. This could be due to the expansion and predominance of new virus variants such as VOC-202012/1 (lineage B.1.1.7), which is thought to be associated with increased transmissibility, a higher reproduction number an increased risk of death $[15,16]$.

Due to the need for healthcare workers to have daily direct contact with COVID-19 patients and despite using protective aids and strong hygienic measures, the number of SARS-Cov-2 positively tested doctors and nurses also increased, with direct negative impacts on the health care system. Under regulations issued by the Ministry of Health of the Slovak Republic, hospital employees are obliged to undergo testing using statesupplied antigen tests every second week. However, many questions were raised about the suitability of the selected testing method, especially regarding its use with large numbers of healthcare professionals and its effectiveness where individuals have low viral load [17-19].

At present, a wide range of methods is available for identifying SARS-CoV-2, including nucleic acid amplification testing (NAAT), serological testing, point-of-care testing, smartphone surveillance of infectious diseases, nanotechnology-based approaches, biosensors and next-generation sequencing (NGS) [20]. The main testing approaches involve detecting the virus itself (viral RNA or antigen) or detecting the human immune response to infection (antibodies or other biomarkers). While whole blood, serum or plasma can be used as a specimen for antibody-based immunoassays, upper or lower respiratory samples are used for antigen-based immunoassays and NAAT [21]. The primary NAAT method is RT-PCR, currently considered to be the gold standard of SARS-CoV-2 detection, and several targeted genomic regions (ORF1b, $N, R d R P, S$ or $E$ genes) have been used in the molecular diagnosis of virus RNA. The serological tests measuring binding antibodies (total immunoglobulins (Ig), IgG, IgM or IgA) make use of the enzyme-linked immunosorbent assay (ELISA), chemiluminescent immune-assays (CLIAs) for quantitative detection and lateral flow immunoassays (LFIA) for the rapid qualitative detection of SARS-CoV-2 [22]. Antigen testing relies on direct detection of SARS-CoV-2 proteins (spike or nucleocapsid) using LFIA. They are substantially less sensitive than NAAT, but on the other hand, they provide rapid, inexpensive and timely detection of the most infectious COVID-19 cases [23].

In this study, we analysed the state of coronavirus infections in Martin University Hospital using one rapid antigen test and three RT-qPCR assays. The City of Martin has nearly 55,000 inhabitants and occupies a central position both in Slovakia and Europe as a whole. It has an excellent hub hospital providing comprehensive healthcare to patients with a wide range of diagnoses, including COVID-19.

\section{Results}

\subsection{SARS-CoV-2 Antigen Detection}

Out of 1231 samples, 14 were evaluated as positive for the presence of SARS-CoV-2 antigens (Figure 1). That extrapolated to a positivity of $1.14 \%$ among the hospital staff. Almost $90 \%$ of positive cases reported experiencing flu- or COVID-19-like symptoms at the time of testing. 


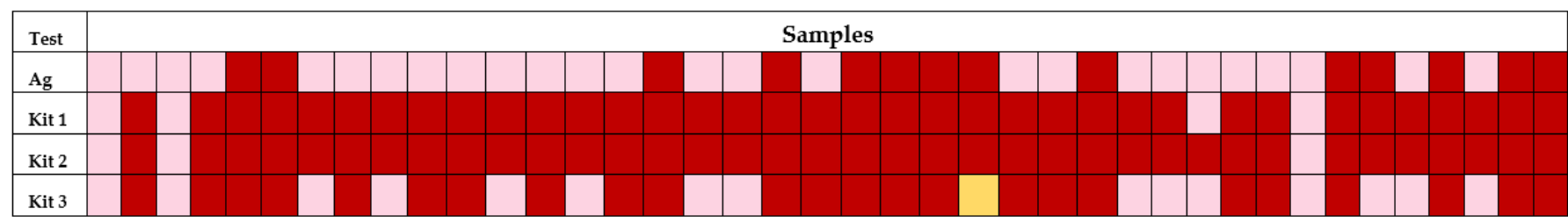

Figure 1. Consistency of positive cases by Ag-antigen test and three different RT-qPCR diagnostic kits, notes: dark red-positive, light red-negative, yellow-inconclusive result/invalid test (sample 826).

\subsection{SARS-CoV-2 RT-qPCR Testing}

Out of 1227 collected naso/oropharyngeal swabs, 1223 produced valid RT-qPCR results. After the first analyses using the vDetect COVID-19 RT-qPCR diagnostic kit (MultiplexDX, Bratislava, Slovakia), we detected 23 positive samples (positivity 1.88\%) and 17 with inconclusive results where there was a positive signal in the Sarbeco gene E but not in the $R d R P$ gene. Such indefinite results are suggestive of a coronavirus infection other than SARS-CoV-2 or a processing error. To check this, all 40 samples (23 positive and 17 inconclusive) were re-isolated and re-analysed with the three RT-qPCR kits on the same day to avoid risks related to RNA freezing. The three tests, respectively returned positive results in 36,37 and 24 cases, giving positivity rates for the samples amounting to $2.94 \%$, $3.03 \%$ or $1.96 \%$. The variability between the diagnostic kits is visualised in Figure 1.

All the $\mathrm{Ct}$ values of the targeted genes in the 40 samples are shown in Figure 2. As can be seen, the same sample with the same pre-analytical processing can have different $\mathrm{Ct}$ values if another assay is used. Slight differences can be observed between kit 1 and kit 2 (Figure 2A,B), except for the samples 32, 974 and 1021. These three samples had either "no $\mathrm{Ct}^{\prime \prime}$ detected by kit 1 or values close to/above 40 , measured by kit 2 . Figure $2 \mathrm{C}$ shows the third testing kit, separately due to its different target genes, where more samples had "no $\mathrm{Ct}^{\prime \prime}$ values with a higher proportion of negative samples than the other two kits detected.

The mean $\mathrm{Ct}$ values and other descriptive parameters of RT-qPCR positive samples detected by three assays are listed in Table 1 and Figure 3. As these kits variate in the sensitivity, chemistry of reagents and gene targets, we provide only row data without statistical comparison between assays. More information about $\mathrm{Ct}$ values and their interpretation can be found in the Section 3 (Discussion).

\subsection{Antigen and RT-qPCR Testing}

All 14 antigen-positive samples were confirmed in RT-qPCR tests using kit 1 and kit 2. Kit 3 failed to detect two samples with an inconclusive result, reporting no $\mathrm{Ct}$ either for targeted genes or RNase $P$ control gene (Figure 1 ).

Moreover, RT-qPCR kit 1, 2 and 3 detected another 22, 23 and/or 12 positive cases respectively, among individuals where the antigen tests had been negative (Figure 1). 


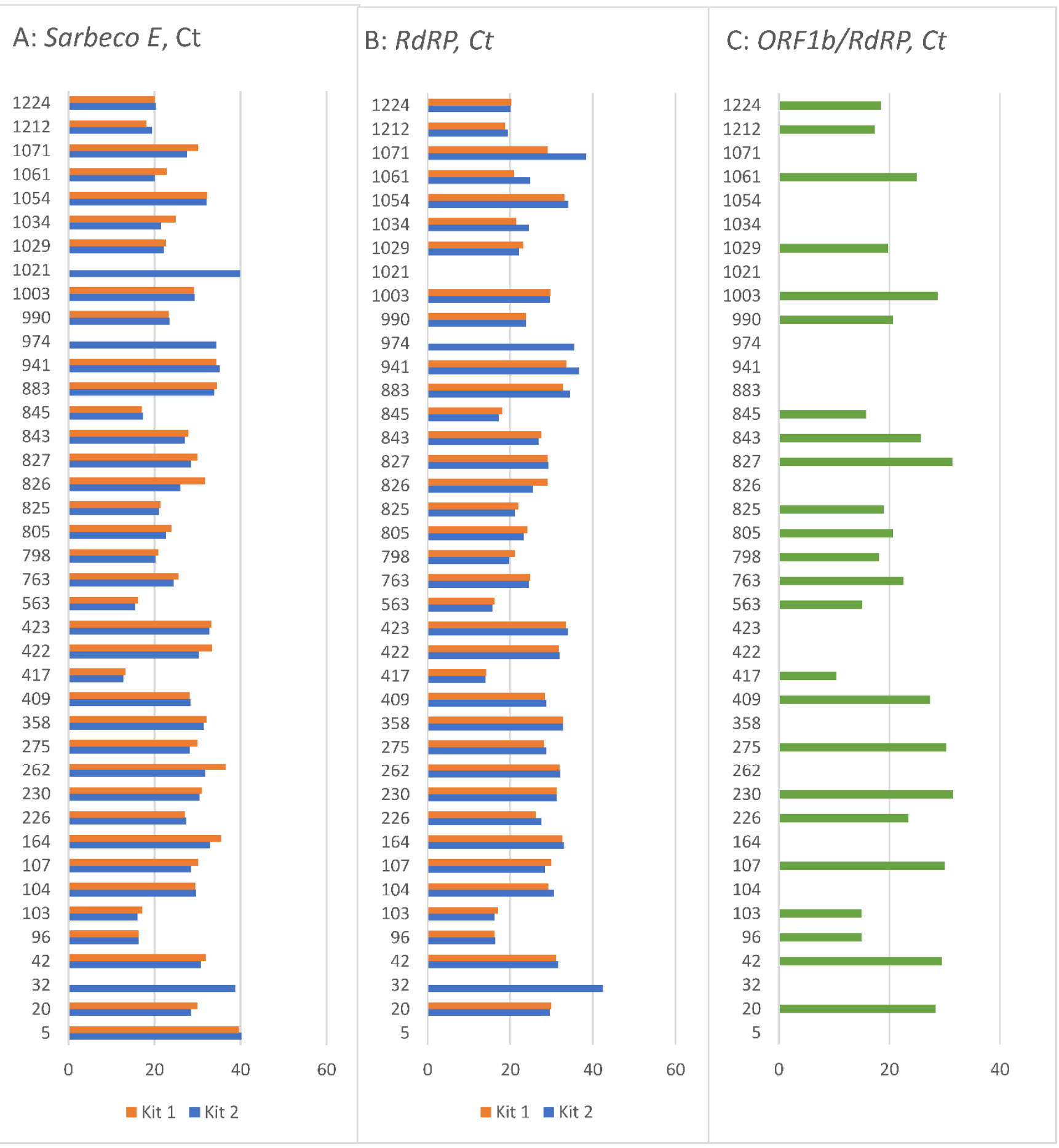

Figure 2. Ct values of selected 40 samples (A) Ct values of Sarbeco E gene by kit 1 and kit 2, (B) RdRP gene by kit 1 and kit 2 , (C) ORF1b and RdRP by kit 3; note: no line = no Ct detected. 
Table 1. Descriptive statistics of Ct values in positive samples.

\begin{tabular}{|c|c|c|c|c|c|}
\hline & \multicolumn{5}{|c|}{ Targeted Genes } \\
\hline & \multicolumn{2}{|c|}{ Kit 1} & \multicolumn{2}{|c|}{ Kit 2} & \multirow{2}{*}{$\frac{\text { Kit } 3}{O R F 1 b / R d R P}$} \\
\hline & $E$ & $R d R P$ & $E$ & $R d R P$ & \\
\hline$n$ & 36 & 36 & 37 & 37 & 24 \\
\hline Median & 28.64 & 28.28 & 27.51 & 28.36 & 21.65 \\
\hline Mean & 26.70 & 26.17 & 25.89 & 26.84 & 22.47 \\
\hline SD & 6.30 & 5.81 & 6.03 & 6.53 & 6.21 \\
\hline Min & 13.24 & 14.16 & 12.80 & 13.96 & 10.45 \\
\hline Max & 36.55 & 33.54 & 35.12 & 38.42 & 31.50 \\
\hline
\end{tabular}

Notes: $n-$ number of samples where the Ct value was detected, SD—-standard deviation, Kit 1 (MultiplexDX), Kit 2-Generi Biotech, Kit 3-BDR Diagnostics.

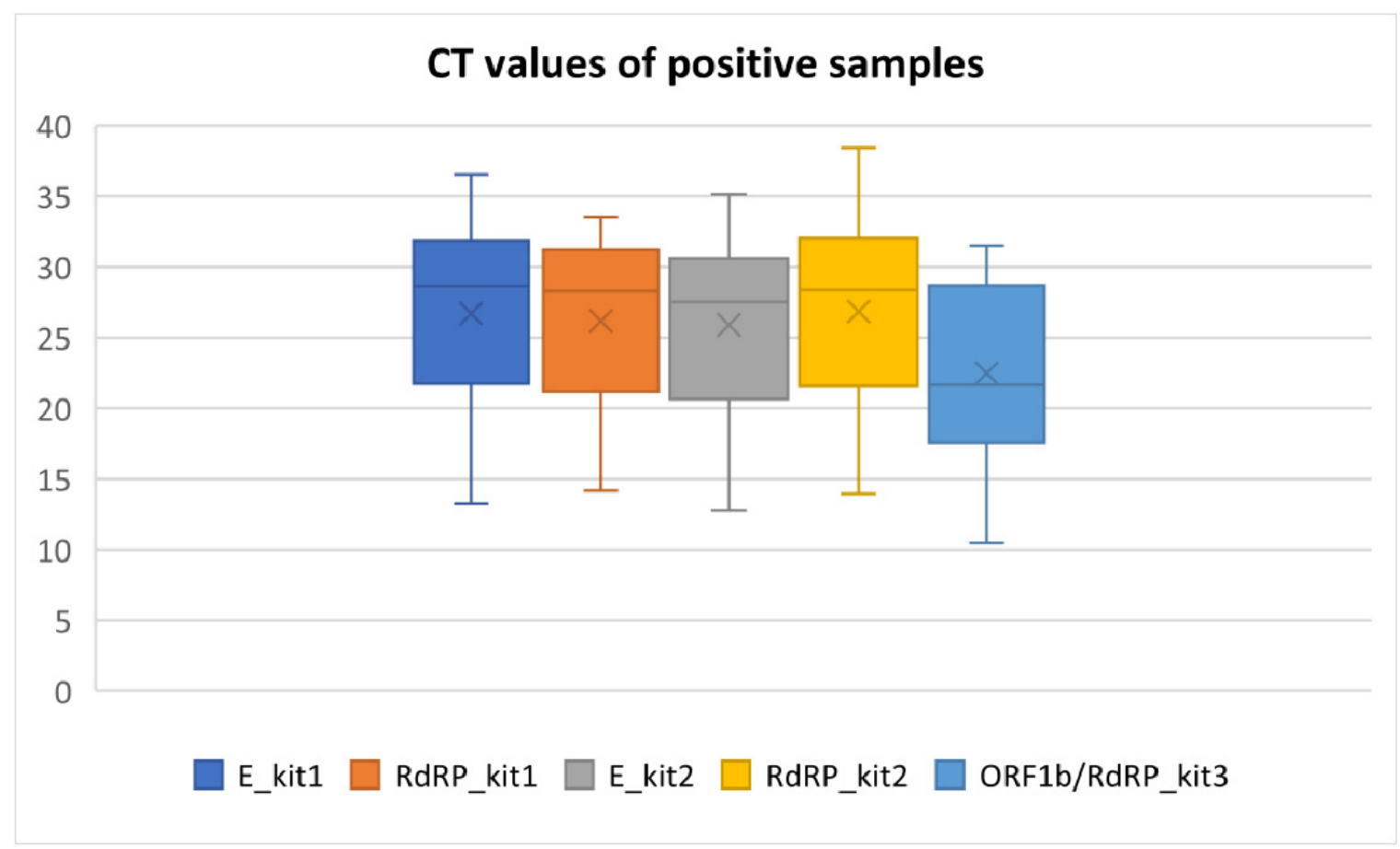

Figure 3. Box plots of measured Ct values of targeted genes by three different diagnostic kits (minimum, first quartile, mean, median, third quartile and maximum are depicted).

Out of these three kits, we selected kit 2 (Generi Biotech, Hradec Králové, Czech Republic) to give the most reliable results, based on our routine laboratory testing experiences, stability of the reagents, clear guidelines for the sample processing and result interpretation, LOD specifications and inclusion of internal RT-PCR control. With this kit, we also passed external quality control for $100 \%$. Therefore, we used data from kit 2 to calculate the sensitivity and specificity of the Standard Q COVID-19 Ag test. It was returned to be $37.84 \%$ and $100 \%$.

Analyses of the performance of the diagnostic antigen test showed the PPV 100\% and NPV 98.10\%, indicating all individuals with positive results were really positive, but $1.9 \%$ of individuals with negative results should have had a positive test result.

Based on the Ag status and RT-qPCR testing, we had two groups: samples Ag and RT-qPCR positive and samples Ag negative but RT-qPCR positive. As seen in Figure 4 and Table 2, the mean Ct values of the first group is about 20, while the mean $\mathrm{Ct}$ values of those not detected by Ag testing were about 30. Roughly, it could be interpreted that the rapid antigen test is only able to detect samples with lower $\mathrm{Ct}$ values corresponding with higher viral load. 

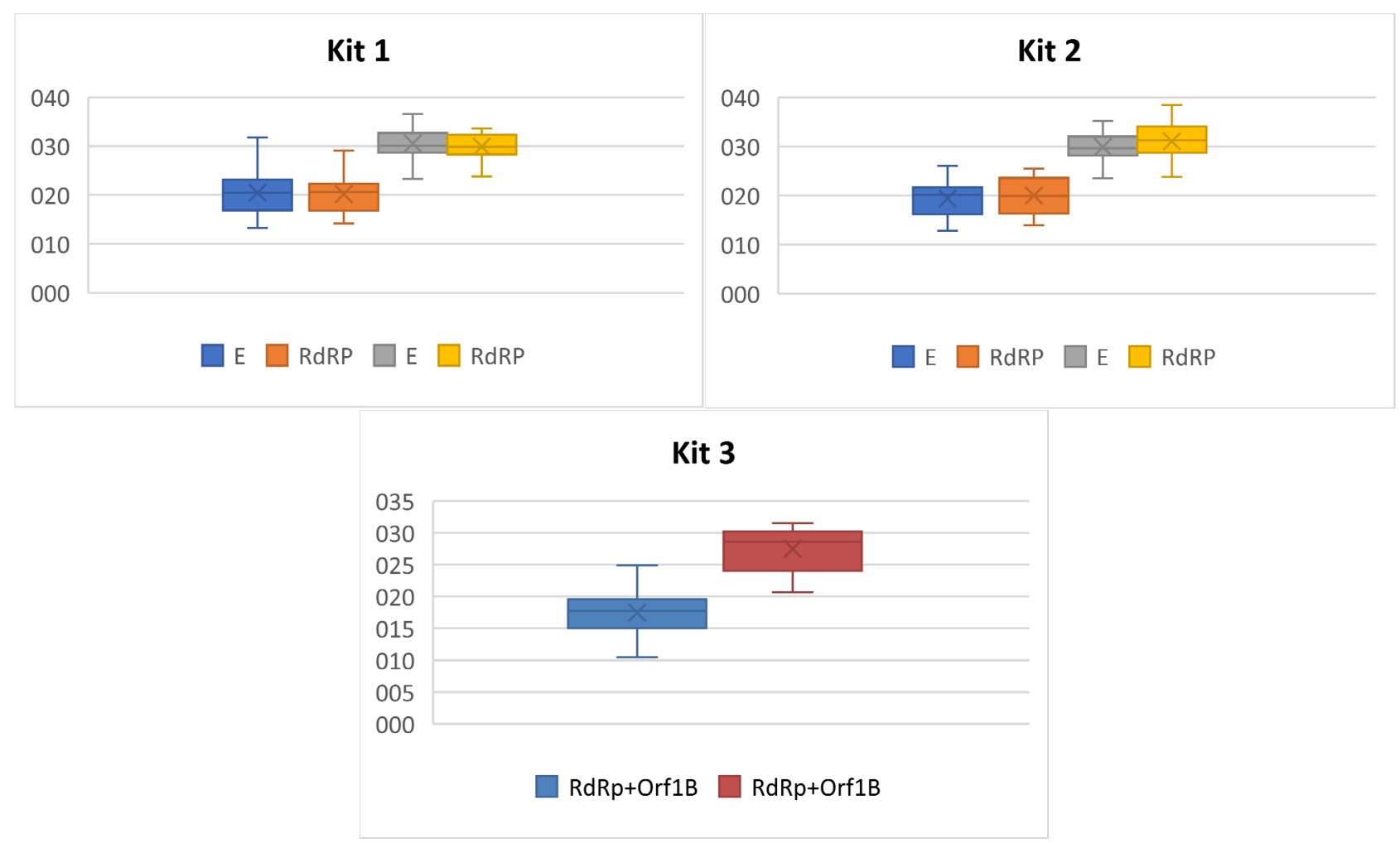

Figure 4. Box plots of SARS-CoV-2 targeted genes Ct values in RT-qPCR positive samples according to the antigen status.

Table 2. Descriptive statistics of Ct values of RT-qPCR samples according to Ag status.

\begin{tabular}{|c|c|c|c|c|c|c|c|c|c|c|}
\hline & \multicolumn{4}{|c|}{ Kit 1} & \multicolumn{4}{|c|}{ Kit 2} & \multicolumn{2}{|c|}{ Kit 3} \\
\hline & \multicolumn{2}{|c|}{$\mathrm{Ag}+$} & \multicolumn{2}{|c|}{ Ag - } & \multicolumn{2}{|c|}{$\mathrm{Ag}+$} & \multicolumn{2}{|c|}{ Ag - } & \multirow{2}{*}{$\begin{array}{c}\mathrm{Ag}+ \\
O R F 1 b / R d R P\end{array}$} & \multirow{2}{*}{$\frac{\mathrm{Ag}-}{\mathrm{ORF1b/RdRP}}$} \\
\hline & $E$ & $R d R P$ & $E$ & $R d R P$ & $E$ & $R d R P$ & $E$ & $R d R P$ & & \\
\hline$n$ & 14 & 14 & 22 & 22 & 14 & 14 & 23 & 23 & 12 & 12 \\
\hline median & 20.48 & 20.61 & 30.14 & 29.92 & 20.10 & 19.90 & 29.62 & 31.20 & 17.77 & 28.59 \\
\hline mean & 20.47 & 20.16 & 30.67 & 30.00 & 19.37 & 19.99 & 29.86 & 31.01 & 17.47 & 27.47 \\
\hline SD & 4.71 & 3.86 & 3.19 & 2.77 & 3.46 & 3.73 & 2.97 & 3.68 & 3.64 & 3.59 \\
\hline $\min$ & 13.24 & 14.16 & 23.31 & 23.76 & 12.80 & 13.96 & 23.52 & 23.74 & 10.45 & 20.70 \\
\hline $\max$ & 31.80 & 29.03 & 36.55 & 33.54 & 26.00 & 25.45 & 35.12 & 38.42 & 24.92 & 31.50 \\
\hline
\end{tabular}

\section{Discussion}

Several different tests have been developed for the diagnosis of COVID-19 since the outbreak of the pandemic. Each of them has specific analytic sensitivity, specificity and time limitation during the disease course (Figure 5) [24-27]. Neither antigen nor antibody detection is applicable for the purpose of early diagnosis. Antibody detection plays a role in serosurveys and can also serve as the proof of clearance from COVID-19 infection. At present, the method of RT-qPCR is considered the gold standard for the early diagnosis of SARS-CoV-2, providing the most accurate results during all disease phases [24,28], although various antigen tests are more widely used. 


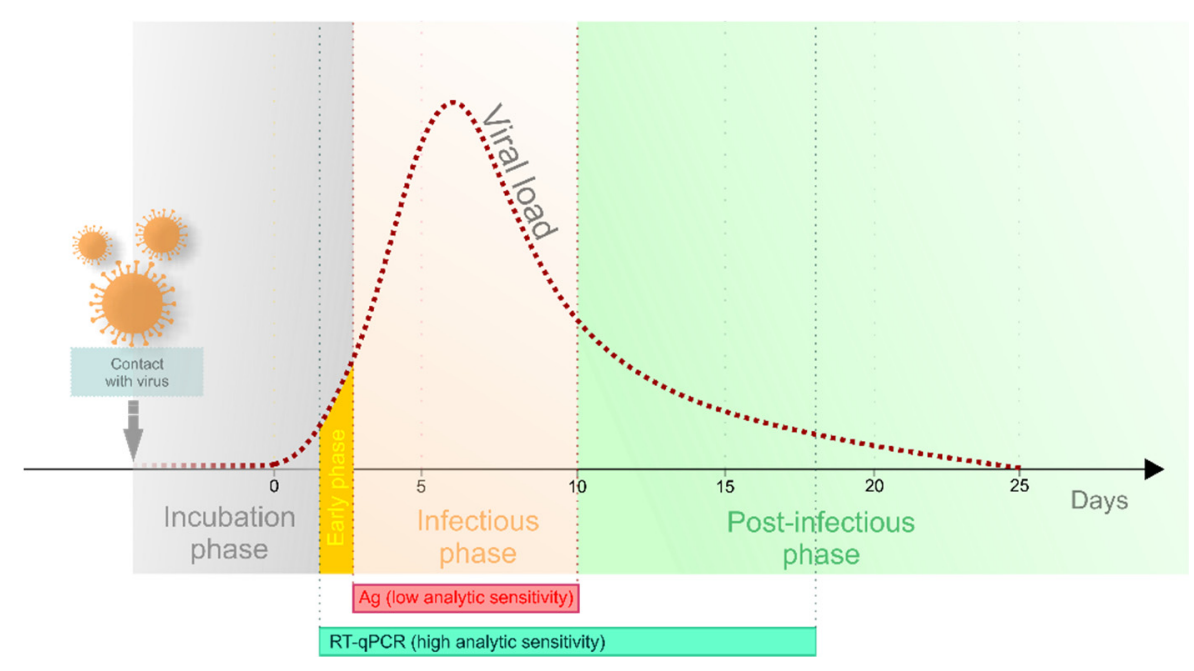

Figure 5. Analytic sensitivity of Ag and RT-qPCR tests, modified from Crozier et al. [29] with permission.

This study provides data-based confirmation of the expected differences between a rapid antigen test and RT-qPCR kits as well as between RT-qPCR assays. Our results have strong local significance in the Slovak Republic as the same rapid antigen tests have been widely used in the massive nationwide testing that commenced in fall 2020 [12,13]. From November 2020 to February 2021, specific institutions, factories and social service facilities were obliged to screen their employees regularly. The use of the tests became even more widespread at the beginning of February 2021, when the "COVID automat" -a set of uniform public health rules for the pandemic-was put into operation. At the highest level of alert then applying, periodic antigen-test screening became compulsory at intervals from 7 to 21 days. Regular testing was obligatory for most of the population until May 2021 [30].

\subsection{Antigen Testing}

In our study, we detected 14 positive samples (out of 1231) with the antigen test, representing $1.14 \%$ positivity among the hospital employees. All these results were confirmed by RT-qPCR kit 1 and kit 2 . Kit 3 confirmed only 12 cases. In addition, the RT-qPCR tests detected another 22,23 or 12 positive samples (this discrepancy might be caused by the different detection limit of the tests, which will be discussed later). Thus, up to 23 false-negative samples were identified and based on the new data; staff positivity was corrected to $3.03 \%$. The negative predictive value (NPV) of the antigen test was calculated to be $98.10 \%$. When extrapolated to the national level, more than 4700 people undergoing antigen tests each day might have been misdiagnosed as negative based on the mean daily total of 250,000 antigen tests in April 2021 [31]. The disadvantages of this low analytic sensitivity should therefore be precisely assessed, and consideration should be given to the question of whether they do not outweigh the advantages. However, after the analyses of Ct values, it can be seen that subjects that were both antigen and RT-qPCR positive had mean and median $\mathrm{Ct}$ values for Sarbeco $E$ and $R d R P$ genes amounting to about 20, whereas the antigen-negative but RT-qPCR-positive samples had these measures of centre close to 30 (details are in Table 2). The inability to detect samples with higher $\mathrm{Ct}$ values is in line with the results of Thommes et al. When investigating subjects with $\mathrm{Ct}$ values higher than 30 , the antigen tests were positive in no more than $45 \%$ of such cases [17]. If the cycle threshold $(\mathrm{Ct})$ values are taken as viral load indicators and prediction markers [32-34], it may be considered a strength of this antigen test (Standard Q COVID-19 Ag test, SD Biosensor) that it detects people at higher risk both on the personal level (risk of more severe disease) and on the population level (risk of viral shedding and transmission). Several studies reported significant associations between the $\mathrm{Ct}$ values at the time of diagnosis or hospital admission and COVID-19 disease severity, number of signs and symptoms, related death as well as sequelae presence several months after the disease [33-36]. 
On the other hand, the individuals with higher $\mathrm{Ct}$ are assumed to have a lower viral load at the time of sampling, and thus, they are considered to pose a lower risk of virus transmission [25]. It would be very useful to know the current health status in such cases when interpreting RT-PCR results. Patients who have overcome the disease and have decreased viral load or residual fragments resulting in a higher $\mathrm{Ct}$ value are of less concern than patients with the same $\mathrm{Ct}$ value who, on the contrary, have an early phase with increasing viral load potential [37]. Such individuals pose a threat because in the course of time, the viral load may exceed the critical level sufficient for effective viral shedding, and such carriers could inadvertently spread the disease despite the "favourable" outcome of the antigen test. Due to the technical limitations of the experiment, we did not perform follow up of the false-negative samples, which we considered to be a weak spot of our study. In our diagnostic practice, we had the opportunity to monitor the dynamic of $\mathrm{Ct}$ values in several patients, and as expected, the results showed a decrease in $\mathrm{Ct}$ values-thus increased viral load at the time of progressive development of the disease and vice versa, increased Ct values - thus decreased viral load-during the clearance of the disease (data not shown). Such observations highlight for us the importance of surveillance. Unfortunately, it is not a part of the standard diagnostic routine in Slovakia.

In this study, no false positivity was detected from the antigen test. In clinical practice, we have encountered a few cases where RT-qPCR verification of a positive antigen test disproved the original result.

In our assessment of the accuracy of antigen testing, we calculated its diagnostic sensitivity and specificity to be $37.84 \%$ and $100 \%$ compared to RT-qPCR results from the second kit. Although the RT-qPCR methodology is accepted as the gold standard, no assay has $100 \%$ accuracy, with the problem more often being lower sensitivity and false negativity than false positivity [38]. Therefore, values of antigen diagnostic accuracy calculated in this way have limitations, are never exact and provide only an approximate estimate.

\section{2. $R T-q P C R$ and $C t$ Values}

This study, besides the demonstration of antigen test unreliability, showed a nonnegligible discrepancy between three different commercial RT-qPCR kits in their identification of 36, 37 and 24 positive cases, respectively.

In our view, these differences could be caused primarily by differences in the limit of detection (LOD), declared to be 2 copies per reaction in kit 1 (vDetect COVID-19 RT-qPCR diagnostic kit, MultiplexDX, Bratislava, Slovakia), 2.13 copies/rxn for kit 2 (gb SARSCoV-2 Multiplex, GENERI BIOTECH, Hradec Králové, Czech Republic) and 10 copies per reaction in kit 3 (Genvinset COVID-19 [E] kit, BDR Diagnostics, Zaragoza, Spain). As we expected based on the LOD, the mean $\mathrm{Ct}$ values of targeted genes were similar in the first and the second kits (Table 1). The third kit, requiring a higher quantity of the virus for reliable detection, based on the weakest LOD parameter, showed lower mean $\mathrm{Ct}$ values. It must be noted that this third test is a one-tube assay detecting both targeted genes in the FAM channel simultaneously, which could have an impact on Ct values. Considering the positivity rates, it appears that either kit 3 has lower sensitivity than kits 1 and 2, or the first and second kit have lower specificity than kit 3. From the molecular point of view, it seems that kits 1 and 2 were able to detect even just a few copies of the virus RNA. Whatever the epidemiology in terms of infectivity of the individual, risk of virus transmission and positive/negative status, as soon as the RNA is detected, the patient should be informed. Additionally, due to COVID-19's character and the rapid spread of the virus, over-diagnosis due to higher sensitivity might be preferable to under-diagnosis because of selecting a kit with higher specificity. The inclusion of results for antibody detection would provide a comprehensive picture of the disease phase.

These results contribute to the ongoing debates on whether to report $\mathrm{Ct}$ values or not, if it has individual utility in clinical decision-making or predicting prognosis and whether it realistically reflects viral load [33,37,39-42]. It is known that Ct values obtained by RT-qPCR can vary. Payne et al. wrote that over $60 \%$ of errors occur in the pre-analytical 
phase of any diagnostic process [43]. In the SARS-CoV-2 context, this phase includes the type of sample, the method of specimen collection, transport medium composition, storage conditions and time from sample collection to the RNA isolation [43,44]. The RNA extraction method and the RT-qPCR assay has also significant impact on Ct values, as demonstrated by this study $[39,40,45,46]$. The selection of the optimal kit is a complex process as the quality of RT-qPCR assays depends on multiple factors. Parameters of great importance include LOD, sensitivity and specificity, avoidance of cross-reactivity with other pathogens, fluorescence parameters and primer quality. Additionally, the inclusion of the human control probe and internal control are vital for the sample quality control and RT-qPCR control. Another key consideration is the stability of the chemical components through repeated thawing and refreezing and the ability to detect not only fresh but also frozen RNA. Based on our evaluation of these factors, we selected the kit from GENERI BIOTECH as the best, meeting the needs of our day-to-day laboratory work. The version of the first kit by MultiplexDX had a perfect LOD but was less satisfactory in its chemical components and $\mathrm{Ct}$ setup. As this company has optimised its assays, another version might have increased quality, similar to their well-working multiplex assay. Kit development and optimisation are ongoing processes all over the world and are ever more urgent as we face the rise and spread of new virus variants. Many different, upgraded commercial kits are available for the diagnosis of patients with SARS-CoV-2 [47-51]. As they significantly differ in the above-mentioned parameters, reporting row $\mathrm{Ct}$ values is very questionable, and $\mathrm{Ct}$ values cannot be directly compared between assays. We showed that one sample can have different $\mathrm{Ct}$ values analysed by three assays. On the other side, identical $\mathrm{Ct}$ from different kits could mean distinct infectivity. The $\mathrm{Ct}$ value of a more sensitive kit represents a lower viral load compared to the same Ct of a less sensitive kit which needs thousands of more virus copies to reach the same Ct. Additionally, as discussed above, the identical Ct detected by the same assay has distinct infectivity potential if an early or late phase is detected. Without clinical data, the RT-PCR test cannot tell the disease phase [44]. Discrepancies between $\mathrm{C} t$ values from different assays could be solved by normalisation by standard curve allowing $\mathrm{Ct}$ translation into copies/mL [52-54]. This serial dilution normalisation and viral load calculation are missing in our study and routine testing as, according to national guidelines, is not required. If all laboratories adopt the normalisation, results of RT-PCR could also have quantitative character informing more precisely about viral load. Additionally, in combination with actual health status and specific guidelines for pre-analytical processing, the RT-PCR testing would be a real "gold standard" technique for SARS-CoV-2 detection. To ensure it, standardised global protocols are needed in this pandemic situation. International authorities or pan-region reference laboratories for SARSCoV-2 detection could take this role and uniform the testing, clearly state the criteria for diagnostic assays as the CE IVD mark does not automatically guarantee high kit quality and reliability and provide guidelines for $\mathrm{Ct}$ translation and virus copies reporting. It is probable that the current pandemic is not the last one. Given the unprecedented growth of the human population, climate change and continuing encroachment into uninhabited areas suitable for wildlife, it seems impossible to prevent interactions between humans and animals, through which more zoonotic viruses such as coronaviruses enter society [6].

\section{Materials and Methods}

\subsection{Subjects and Sampling}

1231 out of 2408 employees of the Martin University Hospital were enrolled in this study for SARS-CoV-2 antigen and RNA detection. Specimens were collected from subjects via naso/oropharyngeal swabs at the same time on 3 and 4 December 2020 (Figure 6). The study was designed in line with the ethical principles of Helsinki declaration and was approved by the Ethics committee (No. EK45/2020). All participants of the study signed informed consent. 


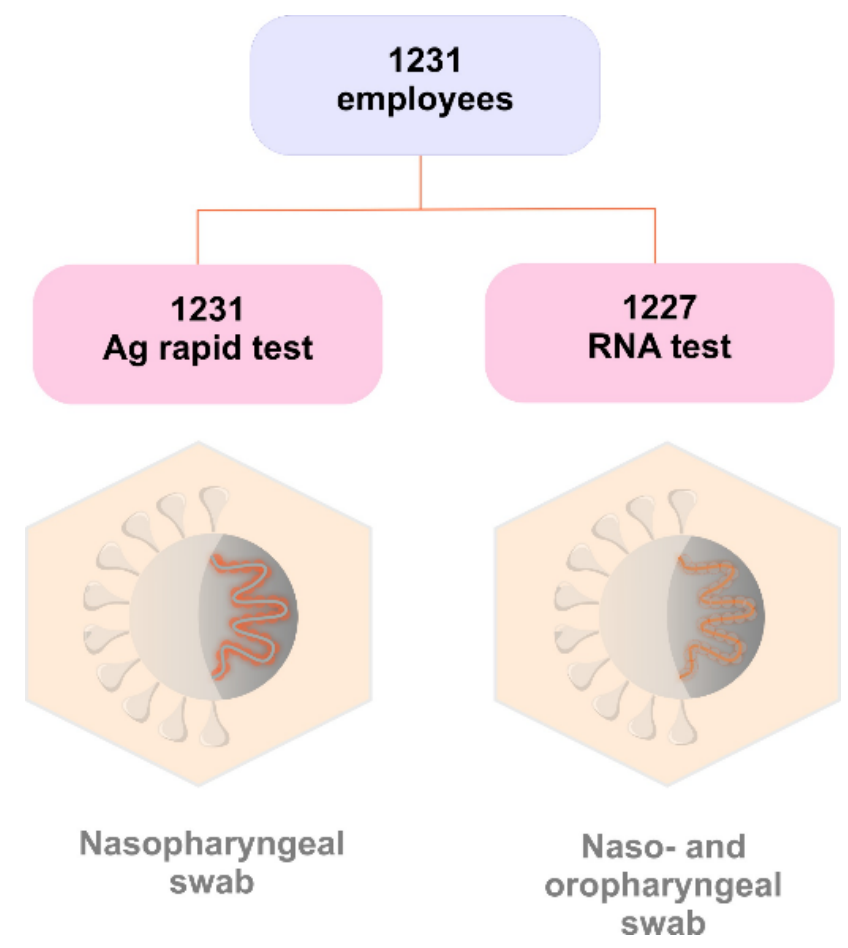

Figure 6. The study design and specimen collection: 1231 nasopharyngeal swabs for rapid detection of nucleocapsid protein and 1227 naso/oropharyngeal swabs for detection of SARS-CoV-2 RNA.

\subsection{Antigen Testing}

The rapid chromatographic immunoassay Standard Q COVID-19 Ag test (SD Biosensor) was used for rapid qualitative detection of SARS-CoV-2 antigens present in the human nasopharynx. This test detects nucleocapsid protein of SARS-CoV-2 by its reaction with mouse monoclonal anti-SARS-CoV-2 antibodies conjugated with colour particles in the device. Testing was performed according to the manual: the nasopharyngeal swab from the nasal cavity was inserted into the extraction buffer, stirred at least 5 times and removed while squeezing the side of the tube. Three drops of extracted specimen were applied to the specimen well of the test device and read after 15-30 min. The samples were evaluated as positive if they had two purple-coloured bands, marking both the $C$ (control) line and the $\mathrm{T}$ (test) line. Samples with a coloured band on only the $C$ (control) line had negative status.

\subsection{RNA Isolation}

Total RNA was extracted using a Quick-RNA ${ }^{\mathrm{TM}}$ Viral 96 kit (Zymo Research, Waltham, MA, USA, cat\#R1041), according to the manufacturers' guidelines and calculated for increased volume of $200 \mu \mathrm{L}$ of the sample. Briefly, $200 \mu \mathrm{L}$ of DNA/RNA Shield ${ }^{\mathrm{TM}} 2 \times$ con- $^{-}$ centrate was added into $200 \mu \mathrm{L}$ of viral transport medium containing the nasopharyngeal swab. Then, the mixture was combined with Viral RNA Buffer and transferred into separate wells in a Zymo-Spin ${ }^{\mathrm{TM}}$ I-96 Plate mounted on a Collection plate. Washing and centrifugation steps were performed, and the viral RNA was eluted with $25 \mu \mathrm{L}$ of DNase/RNase-Free Water into an elution plate and subsequently used for RT-qPCR detection.

\subsection{RT-qPCR Testing by Three Different CE IVD Kits}

All 1231 naso- and oro-pharyngeal swab samples were first analysed using kit 1: vDetect COVID-19 RT-qPCR diagnostic kit (MultiplexDX, Bratislava, Slovakia) consisted of SARS-CoV-2 viral RNA testing using one-step RT-qPCR. It targets the novel coronavirus envelope $(E)$ gene and human $R$ Nase $P$ as the internal control. Positive results were subsequently confirmed by viral RNA-dependent RNA polymerase (RdRP) gene. Each reaction contained a set of primers and hydrolysis dual labeled TaqMan ${ }^{\circledR}$ probes (targeting $E$ or RdRP or RNase P) mixed with the $2 \times$ Brilliant III Ultra-Fast QRT-PCR Master Mix, 
RT/RNase Block, $100 \mathrm{mM}$ DTT and PCR water in total volume of $15 \mu \mathrm{L}$ and $5 \mu \mathrm{L}$ of RNA extracted from nasopharyngeal swab. The thermal cycling conditions were: reverse transcription at $50{ }^{\circ} \mathrm{C}$ for $30 \mathrm{~min}$, initial denaturation at $95^{\circ} \mathrm{C}$ for $3 \mathrm{~min}$ and 45 cycles with denaturation at $95^{\circ} \mathrm{C}$ for $5 \mathrm{~s}$ and annealing/extension at $60^{\circ} \mathrm{C}$ for $20 \mathrm{~s}$. A positive result was interpreted if both viral genes $E$ and $R d R P$ and internal control human $R N a s e P$ amplification curves crossed the threshold line within 40 cycles. As this test gave several inconclusive results, all samples with at least one signal in either the $E$ or $R d R P$ gene were re-isolated and re-analysed by this and other two kits on the same day to avoid RNA freezing as we found that frozen RNA did not work well with the RdRP assay from kit 1 (Table 3).

Table 3. Details of the RT-qPCR kits used in this study.

\begin{tabular}{cccc}
\hline & Kit 1 & Kit 2 & Kit 3 \\
\hline \multirow{2}{*}{ Kit Name } & $\begin{array}{c}\text { vDetect COVID-19 RT-qPCR } \\
\text { Diagnostic Kit }\end{array}$ & gb SARS-CoV-2 Multiplex & Genvinset COVID-19 [E] kit \\
\hline \multirow{2}{*}{ Company } & MultiplexDX, & GENERI BIOTECH s.r.o., \\
Clovak republic & Czech republic & BDR Diagnostics, \\
Spain & $O R F 1 b+R d R P$ \\
\hline Targeted genes & $E, R d R P$ & $E, R d R P$ & $R N a s e P$ \\
\hline Control gene & $R N a s e P$ & $B 2 M$ & $O$ \\
\hline
\end{tabular}

Notes: Gene E-gene encoding the small membrane envelope protein of the SARS-CoV-2 virus, target region general for Sarbecoviruses in kit 2 and specific for SARS-CoV-2 in kit 1; Gene RdRP-gene encoding the RNA-dependent RNA polymerase of SARS-CoV-2 virus; $R N a s e P$-gene encoding human nuclear ribonuclease P; B2M-gene encoding human beta-2-microglobulin; ORF1B - gene encoding open-reading frame $1 \mathrm{~b}$ of the SARS-CoV-2 virus.

Kit 2: gb SARS-CoV-2 Multiplex (GENERI BIOTECH s.r.o., Hradec Králové, Czech Republic) reactions contained the Master Mix OneStep Multi and the Assay CoV-2 E-RdRP or B2M in a total volume of $15 \mu \mathrm{L}$ and $5 \mu \mathrm{L}$ of extracted RNA. Thermal cycling conditions were: reverse transcription at $42{ }^{\circ} \mathrm{C}$ for $30 \mathrm{~min}$, initial denaturation at $95^{\circ} \mathrm{C}$ for $3 \mathrm{~min}$ and 50 cycles with denaturation $95^{\circ} \mathrm{C}$ for $10 \mathrm{~s}$ and annealing/extension at $60^{\circ} \mathrm{C}$ for $30 \mathrm{~s}$ with fluorescence acquisition for FAM, HEX and Cy5 channels. The samples were evaluated as positive if a fluorescence signal was present in the FAM channel specific for the $E$ and B2M genes, and in the HEX channel specific for RdRP. Positive external control was read in the Cy5 channel.

The Genvinset COVID-19 [E] kit (BDR Diagnostics, Zaragoza, Spain) uses Stabilized Amplification Technology-Nucleic Acid Testing (STAT-NAT ${ }^{\circledR}$ ) technology. Lyophilised Master Mixes were reconstituted in $15 \mu \mathrm{L}$ of enclosed buffer to which $10 \mu \mathrm{L}$ of extracted RNA were added. The recommended thermal cycling conditions were reverse transcription at $50{ }^{\circ} \mathrm{C}$ for $10 \mathrm{~min}$, initial denaturation at $95^{\circ} \mathrm{C}$ for $2 \mathrm{~min}, 10$ cycles without fluorescence detection at $95^{\circ} \mathrm{C}$ for $15 \mathrm{~s}$ and at $58^{\circ} \mathrm{C}$ for $30 \mathrm{~s}$ and following 35 cycles with denaturation $95^{\circ} \mathrm{C}$ for $15 \mathrm{~s}$ and annealing/extension at $60^{\circ} \mathrm{C}$ for $30 \mathrm{~s}$ with fluorescence acquisition for the FAM and HEX channels. The sample was evaluated as positive if the fluorescent signal was present in the FAM channel for two target regions of ORF1b and RdRP genes and present or absent in the HEX channel for human RNase $P$ gene as an internal control for amplification. All negative samples presented a signal in the HEX channel.

All qRT-PCR analyses were performed on qTOWER ${ }^{3}$ (Analytik Jena GmbH, Jena, Germany). The RT-qPCR results were analysed using the instrument software (qPCRsoft 4.0) with a constant threshold line setting.

\subsection{Statistical Analyses}

The IBM SPSS statistical program v.21 was used to calculate descriptive statistics. The paired T-test was used to compare the mean $\mathrm{Ct}$ values between diagnostic tests. A nonparametric Wilcoxon test for independent samples was used to compare $\mathrm{Ct}$ values between two diagnostic groups (Ag-positive and Ag-negative samples, both RT-qPCR positive). 
The sensitivity of the rapid antigen test was calculated as true positive/(true positive + false negative) $\times 100$, and the specificity was calculated as true negative /(true negative + false positive) $\times 100$.

We also calculated the performance of the antigen diagnostic test by the positive predictive value (PPV) and negative predictive values (NPV) as follows: PPV = true positive/(true positive + false positive) and NPV $=$ true negative $/($ true negative + false negative).

\section{Conclusions}

To conclude the results of this study by summing up our experience and expectations, the main outcomes could be defined as:

- The results confirmed that the Standard Q COVID-19 Ag test (SD Biosensor) has an advantage in its ability to detect people with lower $\mathrm{Ct}$ values, who can be assumed to have higher viral load and thus pose the highest risk of virus transmission.

- The relatively high number of false-negative results from the antigen test increases the risk of silent virus shedding in the population. If used in mass testing, thousands of individuals could receive incorrect results and proceed to spread the virus, especially if tested at an early phase of viral infection.

- The antigen test is therefore time-limited, and its utilisation in blanket population screening should be re-considered given that the benefit vs. risk ratio is questionable.

- The sensitivity and specificity of an antigen test compared to the gold standard RT-qPCR testing is not accurate unless RT-qPCR sensitivity limits are included in the algorithm.

- Providing row Ct values is not sufficient. We proved that one sample can have variable $\mathrm{Ct}$ values if different assays are used. Moreover, the same $\mathrm{Ct}$ value of kits with different sensitivity represent a discrepant amount of virus copies (even in the thousands). Additionally, identical Ct detected by one kit can have different infectivity aspects depending on the disease phase.

- $\quad$ The algorithm for RT-PCR testing should also calculate actual health status, and if an early phase is suspected, retesting should be considered in the cases when Ct was detected above the threshold resulting in a negative result.

- Clear guidelines for pre-analytical, analytical and post-analytical steps, including chemistry quality, are needed to uniform the testing.

- Normalisation of Ct values by standard dilution curve, counting virus copies could allow inter-kit comparison between laboratories and epidemiological monitoring.

Author Contributions: Conceptualization, Z.D., M.S. (Maria Skerenova), J.S., A.K., M.H., M.A., A.D., V.N., I.K., D.M., D.K., A.C. and E.H.; Data curation: Z.D., M.S. (Maria Skerenova), D.D., D.B., N.K., A.K. and M.H.; Formal analysis, Z.D., E.N., M.S. (Maria Skerenova), V.H., Z.K., S.M., K.J., M.S. (Marek Samec), M.P. (Michal Pokusa), M.P. (Martin Petras), M.S. (Miroslava Sarlinova), I.K. (Ivana Kasubova), D.L., V.S., J.K. and A.S.; Funding acquisition, M.A., D.M., D.K., A.C. and E.H.; Investigation, Z.D., V.H., V.L. and E.H.; Methodology, Z.D., E.N., M.S. (Maria Skerenova), V.H., D.D., D.B., Z.K., J.S., S.M., K.J., M.S. (Marek Samec), M.P. (Michal Pokusa), M.P. (Martin Petras), M.S. (Miroslava Sarlinova), I.K. (Ivana Kasubova), D.L., A.S. and V.N.; Project administration, M.A. and E.H.; Resources, M.A.; Supervision, A.D., I.K. (Ivan Kocan) D.M. and D.K.; Validation, E.N., M.S. (Maria Skerenova) and V.H.; Visualization, Z.D., V.L., M.S. (Marek Samec) and V.N.; Writing—original draft, Z.D., M.S. (Maria Skerenova), V.L., J.S. and E.H.; Writing—eview \& editing, Z.D., E.N., M.S. (Maria Skerenova), V.H., D.D., D.B., Z.K., J.S., S.M., K.J., M.S. (Marek Samec), M.P. (Michal Pokusa), M.P. (Martin Petras), M.S. (Miroslava Sarlinova), I.K. (Ivana Kasubova), D.L., V.S., J.K., N.K., A.K., M.H., A.S., M.A., A.D., V.N., I.K. (Ivan Kocan), D.M., D.K. and A.C. All authors have read and agreed to the published version of the manuscript.

Funding: This publication has been produced with the support of the Integrated Infrastructure Operational Program for the project New possibilities for laboratory diagnostics and massive screening of SARS-Cov-2 and identification of mechanisms of virus behavior in the human body, ITMS: 313011AUA4, co-financed by the European Regional Development Fund. 
Institutional Review Board Statement: The study was conducted according to the guidelines of the Declaration of Helsinki, and approved by the Independent Ethics Committee at the Jessenius Faculty of Medicine, Comenius University in Martin under the No. EK45/2020, on 28 September 2020.

Informed Consent Statement: Informed consent was obtained from all subjects involved in the study.

Data Availability Statement: The data presented in this study are available on request from the corresponding author.

Acknowledgments: The authors would like to gratefully acknowledge the support of Katarína Kramárová, Viera Kšenzuliaková, Ingrid Petríková, Jana Čavojová from the Department of Microbiology and Immunology, Jessenius Faculty of Medicine in Martin for the handling of the samples; Michaela Vladárová and Lucia Matúšková Sliviaková from Clinical Microbiology, Biochémia s.r.o. Žilina for valuable cooperation and support. The authors are grateful to MultiplexDX and BDR Diagnostics for the free donation of the RT-qPCR kits for testing.

Conflicts of Interest: The authors declare no conflict of interest.

\section{Abbreviations}

$\begin{array}{ll}\text { B2M } & \text { the gene encoding human beta-2-microglobulin } \\ \text { COVID-19 } & \text { coronavirus disease 2019, the official name for the disease caused by the virus } \\ \text { Ct } & \text { cycle threshold } \\ \text { E gene } & \text { the gene encoding the small membrane envelope protein of the SARS-CoV-2 virus } \\ \text { LOD } & \text { limit of detection } \\ \text { NPV } & \text { negative predictive value } \\ \text { ORF1B } & \text { gene encoding open-reading frame } 1 \mathrm{~b} \text { of the SARS-CoV-2 virus } \\ \text { PPV } & \text { positive predictive value } \\ \text { RdRP gene } & \text { the gene encoding the RNA-dependent RNA polymerase of the SARS-CoV-2 virus } \\ \text { RNase P } & \text { the gene encoding human nuclear ribonuclease P } \\ \text { RT-qPCR } & \text { quantitative reverse transcription PCR } \\ \text { SARS-CoV-2 } & \text { severe acute respiratory syndrome coronavirus 2, the official name for the virus } \\ & \text { causing the disease }\end{array}$

\section{References}

1. Coronaviridae Study Group of the International Committee on Taxonomy of Viruses. The species Severe acute respiratory syndrome-related coronavirus: Classifying 2019-nCoV and naming it SARS-CoV-2. Nat. Microbiol. 2020, 5, 536-544. [CrossRef]

2. Payne, S. Family Coronaviridae. Viruses 2017, 149-158. [CrossRef]

3. Araf, Y.; Faruqui, N.A.; Anwar, S.; Hosen, M.J. SARS-CoV-2: A New Dimension to Our Understanding of Coronaviruses. Int. Microbiol. 2020, 24, 19-24. [CrossRef]

4. Ur Rehman, M.F.; Fariha, C.; Anwar, A.; Shahzad, N.; Ahmad, M.; Mukhtar, S.; Farhan Ul Haque, M. Novel Coronavirus Disease (COVID-19) Pandemic: A Recent Mini Review. Comput. Struct. Biotechnol. J. 2021, 19, 612-623. [CrossRef] [PubMed]

5. Liu, Y.; Hu, G.; Wang, Y.; Zhao, X.; Ji, F.; Ren, W.; Gong, M.; Ju, X.; Li, C.; Hong, J.; et al. Functional and Genetic Analysis of Viral Receptor Ace2 Orthologs Reveals a Broad Potential Host Range of Sars-Cov-2. Proc. Natl. Acad. Sci. USA 2020, 118, e2025373118. [CrossRef] [PubMed]

6. Chen, Y.; Liu, Q.; Guo, D. Emerging Coronaviruses: Genome Structure, Replication, and Pathogenesis. J. Med Virol. 2020, 92, 418-423. [CrossRef] [PubMed]

7. Kumar, D.; Batra, L.; Malik, M.T. Insights of Novel Coronavirus(Sars-Cov-2) Disease Outbreak, Management and Treatment. AIMS Microbiol. 2020, 6, 183-203. [CrossRef]

8. MacLean, O.A.; Lytras, S.; Weaver, S.; Singer, J.B.; Boni, M.F.; Lemey, P.; Kosakovsky Pond, S.L.; Robertson, D.L. Natural Selection in the Evolution of SARS-CoV-2 in of SARS-CoV-2 in Bats Created a Generalist Virus and Highly Capable Human Pathogen. PLoS Biol. 2021, 19, e3001115. [CrossRef] [PubMed]

9. WHO Coronavirus (COVID-19) Dashboard. Available online: https://covid19.who.int/ (accessed on 1 April 2021).

10. WHO Coronavirus (COVID-19) Dashboard_Global_Slovakia. Available online: https:/ / covid19.who.int/region/euro/country/ sk (accessed on 1 April 2021).

11. Jeong, E.; Hagose, M.; Jung, H.; Ki, M.; Flahault, A. Understanding South Korea's Response to the COVID-19 Outbreak: A Real-Time Analysis. Int. J. Environ. Res. Public Health 2020, 17, 9571. [CrossRef] [PubMed]

12. Pavelka, M.; Van-Zandvoort, K.; Abbott, S.; Sherratt, K.; Majdan, M.; Jarčuška, P.; Krajčí, M.; Flasche, S.; Funk, S. The Effectiveness of Population-Wide, Rapid Antigen Test Based Screening in Reducing SARS-CoV-2 Infection Prevalence in Slovakia. Science 2021, 372, 635-641. [CrossRef] 
13. Frnda, J.; Durica, M. On Pilot Massive COVID-19 Testing by Antigen Tests in Europe. Case Study: Slovakia. Infect. Dis. Rep. 2021, 13, 45-57. [CrossRef] [PubMed]

14. Coronavirus Update (Live): Cases and Deaths from COVID-19 Virus Pandemic. Available online: https://www.worldometers. info/coronavirus/country/slovakia/\#graph-cases-daily (accessed on 1 April 2021).

15. Davies, N.G.; Abbott, S.; Barnard, R.C.; Jarvis, C.I.; Kucharski, A.J.; Munday, J.D.; Pearson, C.A.B.; Russell, T.W.; Tully, D.C.; Washburne, A.D.; et al. Estimated Transmissibility and Impact of SARS-CoV-2 Lineage B.1.1.7 in England. Science 2021, 372, eabg3055. [CrossRef] [PubMed]

16. Challen, R.; Brooks-Pollock, E.; Read, J.M.; Dyson, L.; Tsaneva-Atanasova, K.; Danon, L. Risk of Mortality in Patients Infected with SARS-CoV-2 Variant of Concern 202012/1: Matched Cohort Study. BMJ 2021, 372, n579. [CrossRef] [PubMed]

17. Thommes, L.; Burkert, F.R.; Öttl, K.-W.; Goldin, D.; Loacker, L.; Lanser, L.; Griesmacher, A.; Theurl, I.; Weiss, G.; Bellmann-Weiler, R. Comparative Evaluation of Four SARS-CoV-2 Antigen Tests in Hospitalized Patients. Int. J. Infect. Dis. 2021, 105, 144-146. [CrossRef]

18. Saeed, U.; Uppal, S.R.; Piracha, Z.Z.; Rasheed, A.; Aftab, Z.; Zaheer, H.; Uppal, R. Evaluation of SARS-CoV-2 Antigen-Based Rapid Diagnostic Kits in Pakistan: Formulation of COVID-19 National Testing Strategy. Virol. J. 2021, 18, 34. [CrossRef]

19. Mak, G.C.; Lau, S.S.; Wong, K.K.; Chow, N.L.; Lau, C.S.; Lam, E.T.; Chan, R.C.; Tsang, D.N. Analytical Sensitivity and Clinical Sensitivity of the Three Rapid Antigen Detection Kits for Detection of SARS-CoV-2 Virus. J. Clin. Virol. 2020, $133,104684$. [CrossRef] [PubMed]

20. Eftekhari, A.; Alipour, M.; Chodari, L.; Dizaj, S.M.; Ardalan, M.R.; Samiei, M.; Sharifi, S.; Vahed, S.Z.; Huseynova, I.; Khalilov, R.; et al. A Comprehensive Review of Detection Methods for SARS-CoV-2. Microorganisms 2021, 9, 232. [CrossRef]

21. Alpdagtas, S.; Ilhan, E.; Uysal, E.; Sengor, M.; Ustundag, C.B.; Gunduz, O. Evaluation of Current Diagnostic Methods for COVID-19. APL Bioeng. 2020, 4, 041506. [CrossRef]

22. Carter, L.J.; Garner, L.V.; Smoot, J.W.; Li, Y.; Zhou, Q.; Saveson, C.J.; Sasso, J.M.; Gregg, A.C.; Soares, D.J.; Beskid, T.R.; et al. Assay Techniques and Test Development for COVID-19 Diagnosis. ACS Cent. Sci. 2020, 6, 591-605. [CrossRef]

23. Antigen Detection in the Diagnosis of SARS-CoV-2 Infection Using Rapid Immunoassays. Interim Guidance. Available online: https://www.who.int/publications/i/item/antigen-detection-in-the-diagnosis-of-sars-cov-2infection-using-rapidimmunoassays (accessed on 27 March 2021).

24. Benzigar, M.R.; Bhattacharjee, R.; Baharfar, M.; Liu, G. Current Methods for Diagnosis of Human Coronaviruses: Pros and Cons. Anal. Bioanal. Chem. 2020, 413, 2311-2330. [CrossRef]

25. La Marca, A.; Capuzzo, M.; Paglia, T.; Roli, L.; Trenti, T.; Nelson, S.M. Testing for SARS-CoV-2 (COVID-19): A Systematic Review and Clinical Guide to Molecular and Serological in-Vitro Diagnostic Assays. Reprod. Biomed. Online 2020, 41, 483-499. [CrossRef] [PubMed]

26. West, R.; Kobokovich, A.; Connell, N.; Gronvall, G.K. COVID-19 Antibody Tests: A Valuable Public Health Tool with Limited Relevance to Individuals. Trends Microbiol. 2021, 29, 214-223. [CrossRef] [PubMed]

27. Cevik, M.; Kuppalli, K.; Kindrachuk, J.; Peiris, M. Virology, Transmission, and Pathogenesis of SARS-CoV-2. BMJ 2020, 371, m3862. [CrossRef] [PubMed]

28. Falzone, L.; Musso, N.; Gattuso, G.; Bongiorno, D.; Palermo, C.I.; Scalia, G.; Libra, M.; Stefani, S. Sensitivity Assessment of Droplet Digital PCR for SARS-CoV-2 Detection. Int. J. Mol. Med. 2020, 46, 957-964. [CrossRef] [PubMed]

29. Crozier, A.; Rajan, S.; Buchan, I.; McKee, M. Put to the Test: Use of Rapid Testing Technologies for Covid-19. BMJ 2021, 372, n208. [CrossRef]

30. COVID AUTOMAT.Systém Pre Monitorovanie Vývoja Epidémie A Prijímanie Protiepidemických Opatrenia V Závislosti Od Intenzity Šírenia SARS-CoV-2 (COVID-19). Available online: https:/ / www.minv.sk/?tlacove-spravy\&sprava=covid-automatpravidla-a-vynimky-zo-zakazu-vychadzania-ucinne-od-25-marca (accessed on 27 March 2021).

31. Národné Centrum Zdravotníckych Informácií. Available online: https:/ / covid-19.nczisk.sk/sk (accessed on 13 May 2021).

32. Guglielmi, G. Rapid Coronavirus Tests: A Guide for the Perplexed. Nature 2021, 590, 202-205. [CrossRef]

33. Trunfio, M.; Venuti, F.; Alladio, F.; Longo, B.M.; Burdino, E.; Cerutti, F.; Ghisetti, V.; Bertucci, R.; Picco, C.; Bonora, S.; et al. Diagnostic SARS-CoV-2 Cycle Threshold Value Predicts Disease Severity, Survival, and Six-Month Sequelae in COVID-19 Symptomatic Patients. Viruses 2021, 13, 281. [CrossRef]

34. Rao, S.N.; Manissero, D.; Steele, V.R.; Pareja, J. A Narrative Systematic Review of the Clinical Utility of Cycle Threshold Values in the Context of COVID-19. Infect. Dis. Ther. 2020, 9, 573-586. [CrossRef]

35. Choudhuri, J.; Carter, J.; Nelson, R.; Skalina, K.; Osterbur-Badhey, M.; Johnston, A.; Goldstein, D.; Paroder, M.; Szymanski, J. SARS-CoV-2 PCR Cycle Threshold at Hospital Admission Associated with Patient Mortality. PLoS ONE 2020, 15, e0244777. [CrossRef]

36. Bryan, A.; Fink, S.L.; Gattuso, M.A.; Pepper, G.; Chaudhary, A.; Wener, M.H.; Morishima, C.; Jerome, K.R.; Mathias, P.C.; Greninger, A.L. SARS-CoV-2 Viral Load on Admission Is Associated with 30-Day Mortality. Open Forum Infect. Dis. 2020, 7 , ofaa535. [CrossRef] [PubMed]

37. Yu, F.; Yan, L.; Wang, N.; Yang, S.; Wang, L.; Tang, Y.; Gao, G.; Wang, S.; Ma, C.; Xie, R.; et al. Quantitative Detection and Viral Load Analysis of SARS-CoV-2 in Infected Patients. Clin. Infect. Dis. 2020, 71, 793-798. [CrossRef]

38. Watson, J.; Whiting, P.F.; Brush, J.E. Interpreting a Covid-19 Test Result. BMJ 2020, 369, m1808. [CrossRef]

39. Binnicker, M.J. Challenges and Controversies to Testing for COVID-19. J. Clin. Microbiol. 2020, 58, e01695-20. [CrossRef] 
40. Dahdouh, E.; Lázaro-Perona, F.; Romero-Gómez, M.P.; Mingorance, J.; García-Rodriguez, J. Ct Values from SARS-CoV-2 Diagnostic PCR Assays Should Not Be Used as Direct Estimates of Viral Load. J. Infect. 2020, 82, 414-451. [CrossRef]

41. Gaston, D.C.; Malinis, M.; Osborn, R.; Peaper, D.R.; Landry, M.; Juthani-Mehta, M.; Azar, M.M. Clinical Implications of SARS-CoV-2 Cycle Threshold Values in Solid Organ Transplant Recipients. Am. J. Transplant. 2020, 21, 1304-1311. [CrossRef]

42. Zhang, Z.; Bi, Q.; Fang, S.; Wei, L.; Wang, X.; He, J.; Wu, Y.; Liu, X.; Gao, W.; Zhang, R.; et al. Insight into the Practical Performance of RT-PCR Testing for SARS-CoV-2 Using Serological Data: A Cohort Study. Lancet Microbe. 2021, 2, e79-e87. [CrossRef]

43. Payne, D.; Newton, D.; Evans, P.; Osman, H.; Baretto, R. Preanalytical issues affecting the diagnosis of COVID-19. J. Clin. pathol. 2021, 74, 207-208. [CrossRef] [PubMed]

44. Engelmann, I.; Alidjinou, E.K.; Ogiez, J.; Pagneux, Q.; Miloudi, S.; Benhalima, I.; Ouafi, M.; Sane, F.; Hober, D.; Rousswel, A.; et al. Preanalytical Issues and Cycle Threshold Values in SARS-CoV-2 Real-Time RT-PCR Testing: Should Test Results Include These? ACS Omega 2021, 6, 6528-6536. [CrossRef]

45. Shah, S.; Singhal, T.; Davar, N.; Thakkar, P. No Correlation between Ct Values and Severity of Disease or Mortality in Patients with COVID 19 Disease. Indian J. Med. Microbiol. 2020, 39, 116. [CrossRef] [PubMed]

46. Wang, B.; Hu, M.; Ren, Y.; Xu, X.; Wang, Z.; Lyu, X.; Wu, W.; Li, Z.; Gong, X.; Xiang, Z.; et al. Evaluation of Seven Commercial SARS-CoV-2 RNA Detection Kits Based on Real-Time Polymerase Chain Reaction(PCR) in China. Clin. Chem. Lab. Med. 2020, 58, e149-e153. [CrossRef]

47. Reijns, M.A.M.; Thompson, L.; Acosta, J.C.; Black, H.A.; Sanchez-Luque, F.J.; Diamond, A.; Parry, D.A.; Daniels, A.; O'Shea, M.; Uggenti, C.; et al. A Sensitive and Affordable Multiplex RT-QPCR Assay for SARS-CoV-2 Detection. PLoS Biol. 2020, 18, e3001030. [CrossRef]

48. Marinowic, D.R.; Zanirati, G.; Rodrigues, F.V.F.; Grahl, M.V.C.; Alcará, A.M.; Machado, D.C.; Da Costa, J.C. A New SYBR Green Real-Time PCR to Detect SARS-CoV-2. Sci. Rep. 2021, 11, 2224. [CrossRef] [PubMed]

49. Kudo, E.; Israelow, B.; Vogels, C.B.F.; Lu, P.; Wyllie, A.L.; Tokuyama, M.; Venkataraman, A.; Brackney, D.E.; Ott, I.M.; Petrone, M.E.; et al. Detection of SARS-CoV-2 RNA by Multiplex RTqPCR. PLoS Biol. 2020, 18, e3000867. [CrossRef] [PubMed]

50. Barreto, H.G.; de Pádua Milagres, F.A.; de Araújo, G.C.; Daúde, M.M.; Benedito, V.A. Diagnosing the Novel SARS-CoV-2 by Quantitative RT-PCR: Variations and Opportunities. J. Mol. Med. 2020, 98, 1727-1736. [CrossRef]

51. Jang, W.S.; Lim, D.H.; Yoon, J.; Kim, A.; Lim, M.; Nam, J.; Yanagihara, R.; Ryu, S.-W.; Jung, B.K.; Ryoo, N.-H.; et al. Development of a Multiplex Loop-Mediated Isothermal Amplification(LAMP) Assay for on-Site Diagnosis of SARS CoV-2. PLoS ONE 2021, 16, e0248042. [CrossRef]

52. Han, M.S.; Byun, J.H.; Cho, Y.; Rim, J.H. RT-PCR for SARS-CoV-2: Quantitative versus qualitative. Lancet Infect. Dis. 2021, 21, 165. [CrossRef]

53. Schnuriger, A.; Perrier, M.; Marinho, V.; Michel, Y.; Saloum, K.; Boukli, N.; Lambert-Niclot, S.; Amiel, C.; Fofana, D.B.; Gozlan, J.; et al. Caution in interpretation of SARS-CoV-2 quantification based on RT-PCR cycle threshold value. Diagn. Microbiol. Infect. Dis. 2021, 100, 115366. [CrossRef] [PubMed]

54. Tom, M.R.; Mina, M.J. To interpret the SARS-CoV-2 test, consider the cycle threshold value. Clin. Infect. Dis. 2020, 71, 2252-2254. [CrossRef] 